\title{
Historias en la piedra. La escritura última en los cementerios ingleses de Canarias
}

\author{
RAMÍREZ SÁNCHEZ, Manuel \\ Dykinson, 2016
}

Manuel Ramírez Sánchez

\section{HISTORIAS EN LA PIEDRA}

\section{La escritura última}

en los cementerios ingleses de Canarias

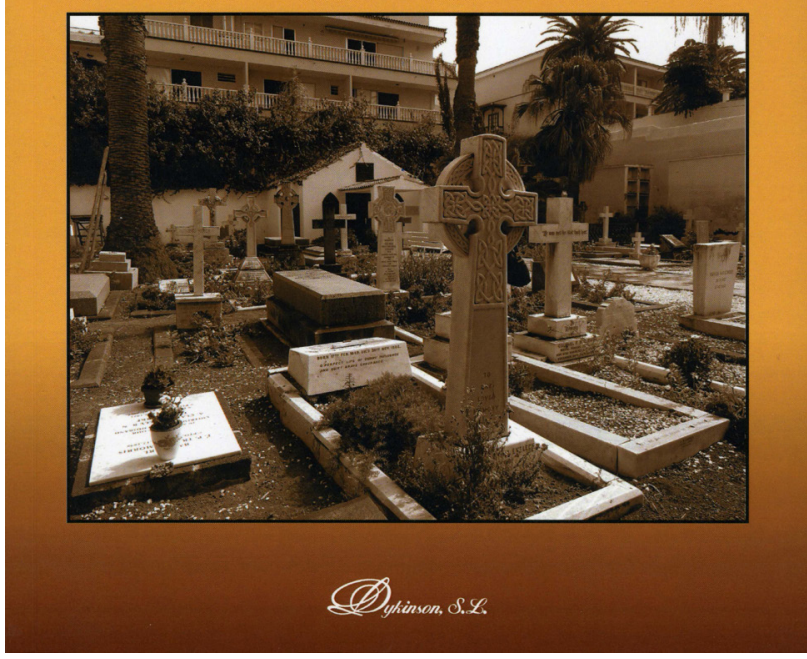

Por razones hoy difícil de aceptar, los cementerios han constituido una parcela del patrimonio cultural olvidada, cuando no maltratada y destruida. Afortunadamente aún estamos a tiempo de rescatar una gran parte de nuestras necrópolis históricas y aprovechar el rico caudal de información que contienen sobre las sociedades que las generaron. Las investigaciones de Manuel Ramírez Sánchez, profesor de Ciencias y Técnicas Historiográficas de la universidad de Las Palmas de Gran Canaria, se enmarcan en los estudios que durante los últimos años se vienen dedicando a analizar la diversidad de valores que coexisten en nuestros cementerios. Este trabajo, abordado desde la disciplina del historia- dor especializado en epigrafía, se enmarca, no obstante, en un contexto multidisciplinar que es difícil de obviar, dada la naturaleza del objeto de estudio. Que el libro que aquí se reseña haya sido publicado por la prestigiada editorial Dykinson debemos interpretarlo como un respaldo a la nueva posición y reconocimiento que los estudios sobre cementerios están alcanzando en el ámbito universitario. Sin embargo, con indudable sagacidad académica, la temática aparece centrada en los cementerios de ingleses o británicos existentes en las islas Canarias: Puerto de la Cruz, Las Palmas de Gran Canaria y Santa Cruz de Tenerife, con una situación y grados de conservación dispares.

El relato teórico se inicia enfatizando la destacable y secular presencia británica en determinadas provincias españolas -las islas Canarias entre ellas-, por razones comerciales fundamentalmente, aunque el viaje de placer y, más recientemente el turismo, también hay que considerarlas para explicar la entidad de esta comunidad. Pero los británicos en suelo español no dejaron de constituir una minoría cultural y religiosa en un periodo caracterizado, incluso desde la oficialidad, por la intolerancia hacia las religiones distintas a la católica. La profesión anglicana, de la iglesia de Escocia, o de cualquier otra opción protestante suponía un problema cuando se producía un fallecimiento, pues al considerárseles disidentes no podían ser inhumados en la tierra sagrada de los "camposantos». Esta problemática, común a todas las localidades con ciudadanos británicos, obtuvo solución con la R.O. de abril de 1830 que permitió construir cementerios segregados para los ingleses, aunque muchos de ellos acabaron acogiendo también a alemanes y personas de otras nacionalidades pero de religión protestante.

Lo que los cementerios ingleses de Canarias pueden aportarnos es, en primer lugar, una vía de acceso al conocimiento de la mentalidad victoriana y su actitud ante la muerte, pues esto es lo que reflejan las tumbas, cuyo mensaje hay que interpretar conociendo las claves de la época -descifradas de forma genérica por autores como Ariés y Vove- 
lle-, y de forma más específica con los testimonios literarios e históricos del momento.

El autor se reconoce seguidor de las líneas de investigación generadas por el paleógrafo italiano Armando Petrucci, aplicadas aquí al estudio del medio millar de lápidas y tumbas analizadas. Aunque, evidentemente, se han transcrito los epitafios de todas ellas, resulta sorprendente lo que las inscripciones nos pueden aportar al margen de su contenido. Los capítulos que siguen recogen exhaustivamente, sin olvidar las proporciones estadísticas, la totalidad de la sorprendente variedad de canteros, marmolistas y lapidarios que realizaron estas tumbas. La mayoría procedían del Reino Unido, donde se realizaban los encargos que llegaban a las Canarias por vía marítima. El hecho de no recurrir a los canteros locales, salvo en contadas ocasiones, resulta ya indicativo de cómo los ciudadanos británicos recurrían al momento del óbito para reafirmarse respecto a sus orígenes, independientemente de su grado de inserción en la comunidad local.

Siguiendo con estos propósitos, se analizan los materiales empleados, las técnicas de ejecución, la tipografía elegida, el simbolismo de flores y plantas, las fórmulas retóricas convencionales y, por supuesto, el contenido de los epitafios. El mensaje de esta «escritura última» no dejaba de constituir la estrategia a la que recurrieron los encargantes para poder elegir la imagen que de sí mismo había de perdurar.

El libro dedica gran parte de su volumen al catálogo completo de todas y cada una de las tumbas, las cuales son fichadas y transcritas con arreglo a las técnicas ampliamente experimentadas en el ámbito académico británico, donde este tipo de estudios cuentan con una dilatada y meritoria tradición. Sin embargo en España este trabajo es novedoso, y su autor apunta la posibilidad de que pueda servir de modelo metodológico para otras investigaciones similares en otros lugares donde aún son necesarios.

Pero el libro de Manuel Ramírez esconde otro laudable propósito, pues a lo largo de sus páginas no ha escondido el preocupante estado de conservación de algunos monumentos funerarios, $y$, en su conjunto, el del cementerio inglés de Santa Cruz de Tenerife. Pese a que algunas de estas necrópolis han obtenido protección jurídica como Bien de Interés Cultural, este máximo reconocimiento no siempre se ha traducido en un plan de actuación que frene el deterioro que implica el desuso. Ahora que el gobierno británico no ejerce su tutela económica y el cambio de usos sociales respecto a la muerte se ha decantado hacia la incineración, se marca un punto de inflexión que equivale también a máximo peligro de destrucción.

Algunas de las lápidas -las de arenisca se han mostrado como especialmente vulnerables a la erosión- resultan de difícil o imposible lectura. En otras ocasiones es la naturaleza de los materiales -letras de plomo, por ejemplo-, lo que tras su deterioro dificulta la interpretación. En este sentido las fotografías decimonónicas procedentes de varios archivos han jugado un papel esencial. Pero no faltan las que han sido víctima de un irracional vandalismo.

Este libro constituye, en sí mismo, una garantía de que el mensaje escrito o mandado escribir por deudos y familiares, no se va a perder. Pero sería deseable que sirviese también para que este patrimonio, abordado aquí con enorme sensibilidad y seriedad metodológica, perdurase también para generaciones futuras.

\section{Francisco José Rodríguez Marín}

